\title{
An Acoustic Experimental Study on the Negative Transfer of Voiceless Plosive Codas by Chaoshanese EFL Learners
}

\author{
Huan-Biao Hu, Long Ye* \\ School of Foreign Languages, Shaoguan University \\ Shaoguan, China \\ *Corresponding author: bobyeesgu@163.com
}

\begin{abstract}
In this research, Chaoshanese EFL learners are studied from the perspective of experimental phonetics. The research believes that the phonological characteristics of entering tone of the Chaoshan dialect will be negative for the students with mother tongue of the Chaoshan dialect to acquire the voiceless plosive codas in English monosyllables. The authors used tables to mark down the pronunciation of the English monosyllable voiceless plosive codas made by the students interviewed, sonograms are made up to compare the pronunciation of the articulators with mother tongue of the Chaoshan dialect and pronunciation of English standard sound. According to the statistics, the authors did an error analysis of the articulators with mother tongue of the Chaoshan dialect for pronouncing English monosyllabic voiceless plosive codas. The errors are mainly characterized by unreleased stop and minor insertion made by the students tested. Aiming at these principal errors, The authors gave their advice on teaching and learning of English voiceless plosive codas to Chaoshanese learners.
\end{abstract}

Keywords-Chaoshan dialect; English; Voiceless plosive codas; Negative transfer; Sonogram

\section{INTRODUCTION}

Negative Transfer is derived from Contrastive Analysis Hypotheses $(\mathrm{CAH})$. The hypothesis holds that when some forms and meanings of a second language are the same as or similar to those of a learner's mother tongue, it is easier for him to learn; otherwise, differences between the two languages will be difficulties and obstacles in language learning [1].

As both a Chaoshanese speaker and an English learner, to an extent, one of the authors of this paper has a relatively comprehensive understanding of English learners' phonetic features in this area. The Chaoshanese, like other English learners in China, have common problems -- segmentally phonemically in distinguishing Chinese simple finals and English monophthongs, Chinese compound finals and English diphthongs, Chinese initials and English consonants; suprasemental phonemically in difference between syllable structures, stress patterns, phonetic rhythm patterns and tone patterns. Chaoshanese English learners suffer from the negative transfer when pronouncing consonants, especially voiceless plosive codas $/ \mathrm{p} /, \mathrm{t} / \mathrm{/} / \mathrm{k} /$.

Under such circumstance, to discover what features their errors are in pronouncing English plosives, how they acquire, what affects their acquisition, and what can be improved in teaching consist the purpose of this research.

Previously, phonetically experimental study of the negative transfer of voiceless plosive codas by Chaoshanese EFL learners was scarcely made. Therefore, this experimental study of it will serve second language teaching in Chaoshan area, and its conclusion could also be applied by all Chaoshanese EFL learners around the world.

\section{A REVIEW OF RELATED STUDIES}

\section{A. Studies of Negative Transfer by Dialects}

Kong reveals the influence of the phonetic system of Shandong dialect on the students' English learning from the region and discussed how teachers can effectively predict and correct students' errors in English teaching by comparing the similarities and differences between Shandong dialect and English phonetic system. He points out that some consonants in English and some initials in Mandarin is almost the same or similar, and many phones are absent in some of Shandong dialect [2]. Therefore, speaking Mandarin well is helpful for mastering these pronunciations.

A more detailed comparative analysis and research on phonology of Sichuan dialect and English is carried out by Ma, analyzing the differences between the two phonologies [3]. $\mathrm{He}$ also analyzes the ubiquitous errors made by learners in Sichuan dialect area in two aspects: Segmental Element and Suprasegmental Element [3].

Liu presented four statements on the negative transfer in learning English caused by the Chaoshan dialect. Firstly, students cannot distinguish between long and short vowels, such as $[\mathrm{u}]$ and $[\mathrm{u}:]$. Secondly, they tend to replace vowels by using a native one, for example, equating [æ] with [e]. Thirdly, they seem not to distinguish between retroflex and lateral. Last but not least, fricatives are hard for them to pronounce, especially interdentals and labiodentals [4].

On the basis of extensive retrieval and reading, this study found that most of the studies on the negative transfer by dialects are relatively simple and rough, lacking error analysis of key and difficult points from the perspective of experimental phonetics so that an inadequacy of practical relevance, 
guidance and effectiveness of what have been proposed on teaching strategies and teaching methods is inevitable.

\section{B. Studies of the Acoustic Phonetics of Plosive and Studies of Plosive Acquisition}

Yin compares plosives and nasals in English with plosive codas in Mulao language. He believes that phones between the two languages are different [5], but he did not give any suggestion on teaching of English plosives. In 2010, he once again compares and analyzes these sounds between English and Maonan language. He considered it is necessary, through the study of similarities and differences between learners' national language and English in pronunciation, to find out the rules to guide the minority students to pronounce accurately [6]

According to Flege, in the process of second language acquisition, a "new" sound is easier to learn than a "similar" sound [7]. For Chinese students in the north of China, English voiced plosive is a new sound because it is absent in Mandarin, and English voiceless plosive is similar to Mandarin plosive. On the impact of Equivalent Classification, a new sound is easier to grasp than a similar one.

Liu makes a comparison of initials of the Chaozhou dialect and English consonants in the manner of pronunciation, pointing out that due to the limited number of initial consonants, few places of pronunciation and relatively simple manners of pronunciation in their dialect, students from Chaozhou have problems mainly in labiodental, interdental, position of the tongue and so on when pronouncing English consonants [8]. In addition, in the Chaozhou dialect, alveolar nasalization of some of voiced initials will transfer, such as inadequate plosion.

\section{EXPERIMENT DESIGN}

\section{A. Experiment Hypothesis}

According to the theory of Negative Transfer, we know that the syllable structure of entering tones in the Chaoshan dialect will bring negative transfer to Chaoshan EFL learners. Specifically, voiceless plosive codas of entering tones in the Chaoshan dialect /p/, /t/, /k/, are unreleased, which will affect the learners to pronounce the English monosyllabic voiceless plosive codas. Due to the negative transfer, their codas are always too weak to be audible. Learners tend not to release the codas, so it turns out to be a phenomenon of "swallowing sound". They are pronounced as unreleased stops, transcribed as $\left.[\mathrm{p}\urcorner],\left[\mathrm{t}^{\urcorner}\right],[\mathrm{k}\urcorner\right]$.

In this study, the author only used the English monosyllables ended with voiceless plosive as the experimental material to avoid the influence from the mutations of polysyllabic words and liaison.

\section{B. Experimental Objects}

The experiment selected 32 students whose mother tongue is the Chaoshan dialect from Shaoguan University as the objects of experiment. They are aged from 18 to 23, and there are 16 male students and 16 female students are tested.

\section{Experimental Materials}

The experiment used 18 English words ended with voiceless plosive codas, and they are divided into two groups: 9 short vowels and 9 long vowels. There are respectively 3 words ended with $/ \mathrm{p} /, / \mathrm{t} /, / \mathrm{k} /$ in each group. In the right column of the table, The Authors used words from the Chaoshan dialect phonetically similar to English words. The words are listed in the following tables.

TABLE I. SHORT VOWELS WITH VOICELESS PLOSIVE CODAS

\begin{tabular}{|c|c|c|}
\hline No. & English word & $\begin{array}{l}\text { Chaoshanese } \\
\text { word }\end{array}$ \\
\hline S1 & up & 盒 $[a p\urcorner]$ \\
\hline $\mathrm{S} 2$ & sup & 刹[sap`] \\
\hline S3 & $\operatorname{sip}$ & 湿 [sip $\urcorner$ \\
\hline $\mathrm{S} 4$ & bit & 笔[pit $]$ \\
\hline S5 & sit & 实[ sit $\left.^{\top}\right]$ \\
\hline S6 & chit & 七[tsit $\left.{ }^{\top}\right]$ \\
\hline S7 & buck & 北[pak $\left.{ }^{\top}\right]$ \\
\hline S8 & lock & 录[ $\left[\mathrm{lok}^{\top}\right]$ \\
\hline S9 & sock & 束 $\left[\right.$ sok $\left.^{\urcorner}\right]$ \\
\hline
\end{tabular}

TABLE II. SHORT VOWELS WITH VOICELESS PLOSIVE CODAS

\begin{tabular}{|c|c|c|}
\hline No. & English word & $\begin{array}{l}\text { Chaoshanese } \\
\text { word }\end{array}$ \\
\hline L1 & keep & 级 $\left[\mathrm{k}^{\mathrm{h} i \mathrm{ip}}\right]$ \\
\hline L2 & jeep & 集[jip’] \\
\hline L3 & leap & 立[lip?] \\
\hline L4 & beat & 必[pit?] \\
\hline L5 & meet & 密[mit $\left.{ }^{7}\right]$ \\
\hline L6 & boot & 不[put? \\
\hline L7 & seek & 式[sik $\left.{ }^{\urcorner}\right]$ \\
\hline L8 & park & 博 $\left[\mathrm{p}^{\mathrm{h}} \mathrm{ak}^{\urcorner}\right]$ \\
\hline L9 & hark & 学[hak’] \\
\hline
\end{tabular}


The experiment selected 32 students whose mother tongue is the Chaoshan dialect from Shaoguan University as the objects of experiment. They are aged from 18 to 22, and there are 16 male students and 16 female students are tested.

\section{Experimental Methods}

The Composition of the Experiment: The experiment was carried out by recording English monosyllables with voiceless plosive codas pronounced by students whose mother tongue is the Chaoshan dialect. There are both short vowels and long vowels in these monosyllables.

Experimental Software: Cool Edit Pro 2.1 : It is a speech editing and analyzing software for recording and editing audio data. The sample rate is $16,000 \mathrm{~Hz}$, the quantization precision is 16 bit, and the track type is monotrack.

Data and Data Processing: The experiment had 9 English monosyllabic short vowels ended with voiceless plosives recorded from 32 students of the Chaoshan dialect, that is, a total of 288 pieces of data; 9 English monosyllabic long vowels ended with voiceless plosives recorded from 32 students of the Chaoshan dialect, that is, a total of 288 pieces of data. A total of 576 pieces of data recorded was edited. The data of the experiment are judged and marked down one by one. The data of the correct and incorrect data are analyzed quantitatively. According to the recordings, sonograms were made to show the specific forms of every datum to verify the experimental hypothesis.

\section{EXPERIMENTAL STUDY OF CHAOSHANESE ARTICULATORS}

\section{A. Articulations}

There are 32 articulators of the Chaoshan dialect. They are required to read the given words at normal speed for 4 times.

Articulations of Monosyllabic Short Vowels with Voiceless Plosive Codas: The following figure shows the pronunciation of monosyllabic short vowels with voiceless plosive codas. To be specific, the words ended by $/ \mathrm{p} /$ are incorrectly pronounced at an average of 16.7 times each person, $/ \mathrm{t} /$ at an average of 14.7 times each person, /k/ at an average of 15 times each person.

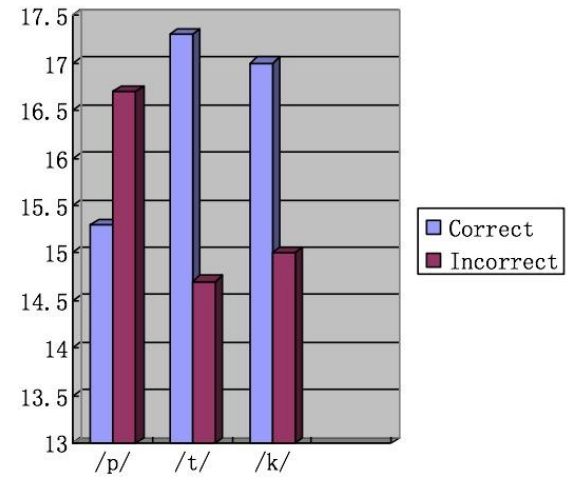

Fig. 1. Errors of short vowels with voiceless plosive codas
Articulations of Monosyllabic Long Vowels with Voiceless Plosive Codas: Fig.2. shows the pronunciation of monosyllabic short vowels with voiceless plosive codas. To be specific, the words ended by $/ \mathrm{p} /$ are incorrectly pronounced at an average of 15 times each person, /t/ at an average of 14.3 times each person, $/ \mathrm{k} /$ at an average of 17 times each person.

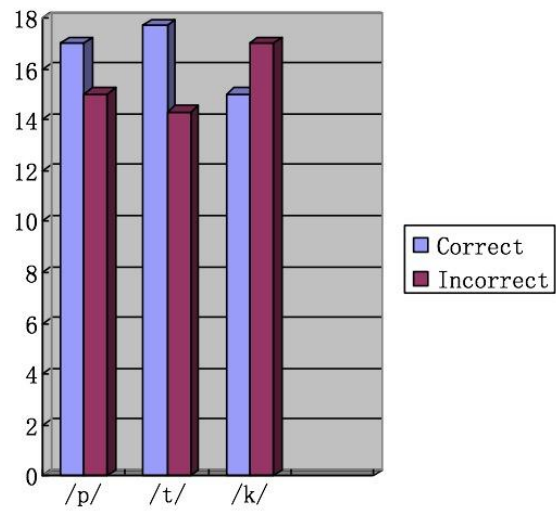

Fig. 2. Errors of long vowels with voiceless plosive codas

\section{B. Data Analysis of the Experiment}

Error Statistics of Monosyllables with Voiceless Plosive Codas: In the experiment, 576 pieces of data have been marked down as follow:

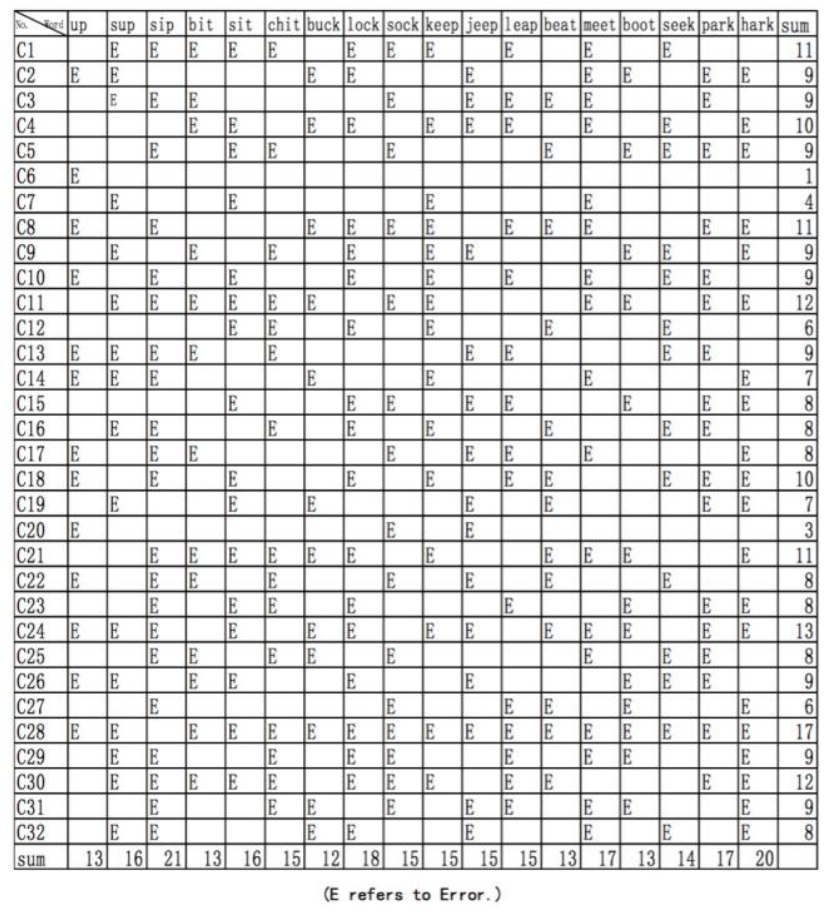

Fig. 3. Experimental data

Accordingly, the data in Fi.3. made up a bar figure to display the errors made by the students. The figure is as follow: 


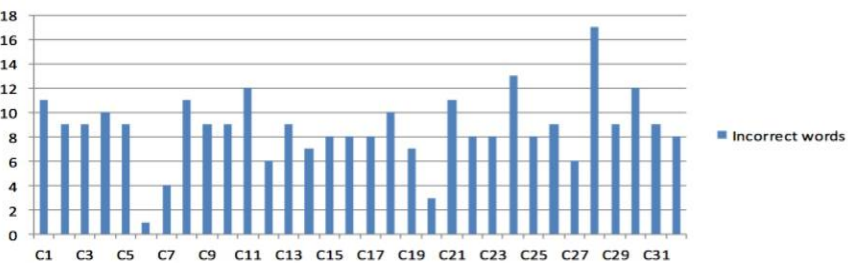

Fig. 4. Experimental data

It shows us the most frequently error making speaker is C28, for 17 times, then $\mathrm{C} 24$ for 13 times. The best speaker of the test is C6, and he only made errors for 1 word.

\begin{tabular}{|l|r|r|r|}
\hline & $/ \mathrm{p} /$ & $\mathrm{t} /$ & $/ \mathrm{k} /$ \\
\hline Correct & 32.3 & 35 & 32 \\
\hline Incorrect & 31.7 & 29 & 32 \\
\hline
\end{tabular}

\begin{tabular}{|l|c|l|l|}
\hline & $/ \mathrm{p} /$ & $/ \mathrm{t} /$ & $/ \mathrm{k} /$ \\
\hline Correct & $50.47 \%$ & $54.69 \%$ & $50.00 \%$ \\
\hline Incorrect & $49.53 \%$ & $45.31 \%$ & $50.00 \%$ \\
\hline
\end{tabular}
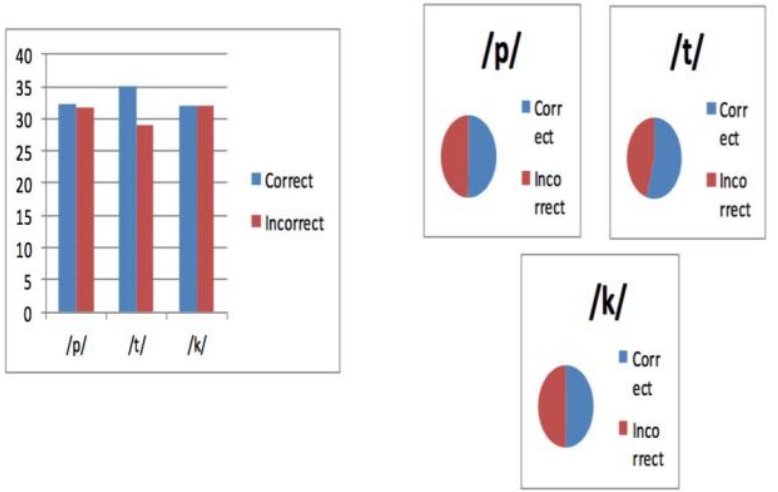

Fig. 5. Proportion of the errors

As shown in Fig.5., the error rate of $/ \mathrm{p} /$ is $49.53 \%$, that is to say, half the monosyllables with voiceless plosive codas are read incorrectly; the error rate of $/ \mathrm{t} / \mathrm{is} 45.31 \%$; the error rate of $/ \mathrm{k} /$ is $50 \%$. In short, the error rates of the three plosive codas are high.

\section{RESULTS AND DISCUSSION}

\section{A. Performance of Voiceless Plosive Codas}

Pulse waves that the plosive makes in the period of release, is reflected on the sonogram as spike. Its presence tells whether the process of release occurs. The Authors asked a native English speaker (a foreign teacher as Shaoguan University) to read the words in the experiment, and made up their sonograms by Cool Edit Pro 2.1. The sonograms are as follow:

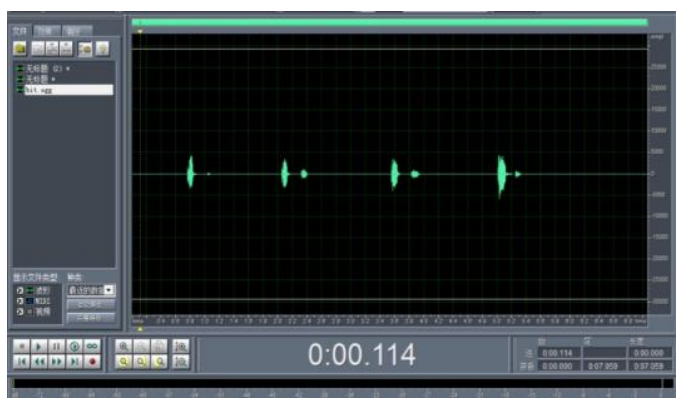

Fig. 6. Proportion of the errors
It shows the waveform of word "bit" read by the teacher (for 4 times). The dot behind the long bar is called spike, which is the reflection on the waveform of the voiceless plosive coda $/ \mathrm{t} /$. It also means plosive airstream.

If there is no spike on the waveform, we can infer that the coda is replaced by unreleased stops or no audible releases, so $\mathrm{C} 4$ pronounced "bit" incorrectly for 4 times.

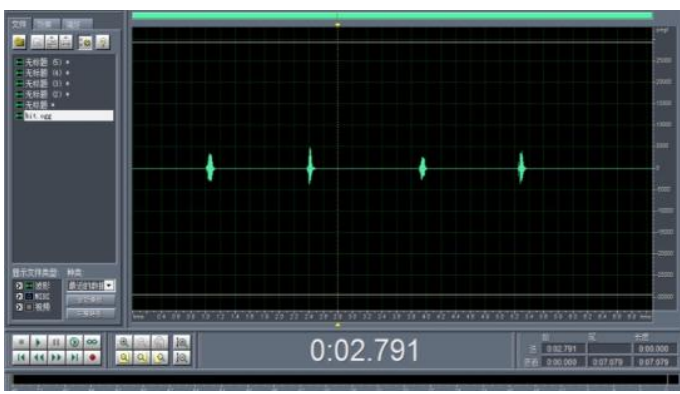

Fig. 7. The sonogram of "bit" by $\mathrm{C} 4$

The Authors made up 4 more sonograms to verify the experiment.

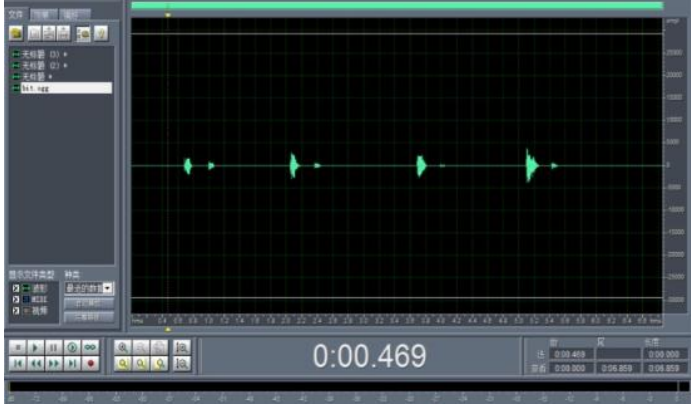

Fig. 8. The sonogram of "buck" by the teacher

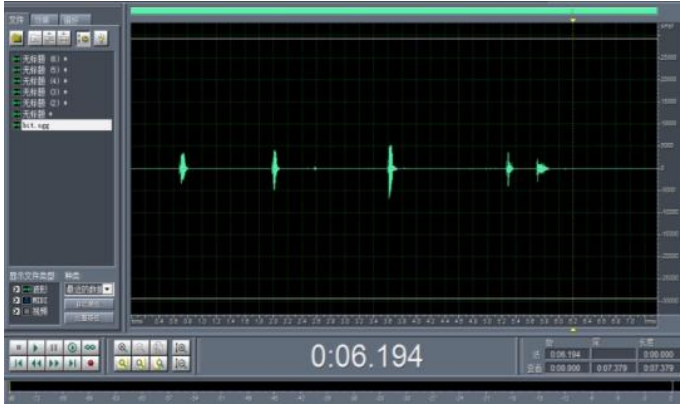

Fig. 9. The sonogram of "buck" by $\mathrm{C} 21$

In Fig.9., for the former three times, C21 read the word "buck" as unreleased stop, transcribed as $[\mathrm{b} \Lambda \mathrm{k}]$. When he read the fourth time, he added a phone [ə] after [k], which isreflected on the waveform as something like a bar instead, not a dot. What he read is transcribed as [b $\mathrm{k}$ kə]. 


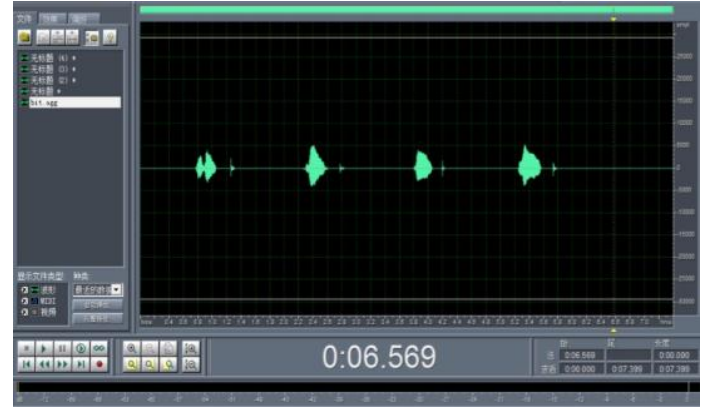

Fig. 10. The sonogram of "leap" by the teacher

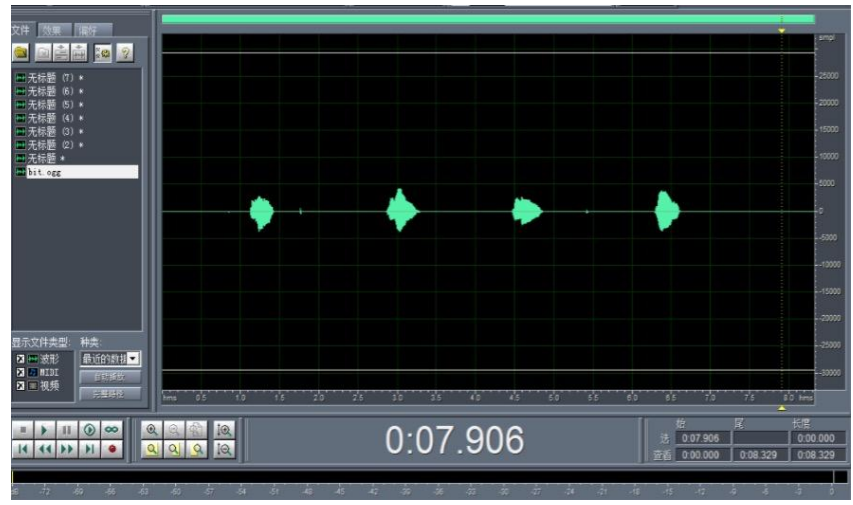

Fig. 11. The sonogram of "leap" by C27

Ancient entering tones are maintained in the Chaoshan dialect. They are described as no audible releases. According to these descriptions, to read an entering tone correctly, we should read the plosive codas as no audible releases, transcribed as $[\mathrm{p}\urcorner],[\mathrm{t}\urcorner],[\mathrm{k}\urcorner]$.

\section{B. The Negative Transfer of Voiceless Plosive Codas by the Chaoshan Dialect}

Through the experiment the analysis, we can infer:

(1) When the students of the experiment pronounced the monosyllabic voiceless plosive codas, they made errors at a high rate, especially $/ \mathrm{k} /$, for $50 \%$. Some students even had just correctly pronounced merely several words, especially C6 for 1.

(2) The errors are due to neither liaison, nor teaching in English classes. They are from the influence of students' mother tongue, that is, the feature of plosive codas in ancient Chaoshanese entering tones. Voiceless plosive codas /p/, /t/, / / / in English are pronounced as no audible releases in the Chaoshan dialect. This is a process of negative transfer.

(3) Due to no equivalent of syllable structure in the Chaoshan dialect, when pronouncing an English monosyllable with voiceless plosive codas, some students are often apt to add a vowel after [p], [t], [k], thus as [pə], [tə], [kə].
(4) According to Equivalence Classification, the learner classifies the similar phones into a certain category of the mother tongue. It leads to the fact that the learner's pronunciation always comes with the accent of his mother tongue. Equivalence Classification talks about phones, but the method is also applicable to syllables.

In English, there is syllable structure of CVC (consonant + vowel + consonant). Likewise, in the Chaoshan dialect, there is also CVC. Therefore, when Chaoshanese EFL learners acquire monosyllables with voiceless plosive codas, they tend not to release the codas, but use the structure of entering tones instead As The Authors mentioned above, voiceless plosive codas in English are, in fact, released voiceless plosives, while those in the Chaoshan dialect, are unreleased stops.

As for insertion, though a phenomenon of error making by the students, is not what this research studies because it is relevant to phones. This research is focused on plosive onsets.

\section{CONCLUSIONS}

With the help of a speech editing and analyzing software, this acoustic experimental study, by an analysis of reading of the English monosyllabic words ended with voiceless plosive codas from Chaoshanese students, shows errors made by the students. Most students, affected by the negative transfer from Chaoshanese entering tones, read the given words as unreleased stops, which are also called implosives. The results of study reveal the problems of Chaoshanese students when they pronounce English plosives codas, to a larger extent, their phonetic problems.

\section{REFERENCES}

[1] R. Lado, Linguists Access Cultures. Michigan: University of Michigan, Ann, Arbor, 1957.

[2] J. Kong, The Influence of Shandong Dialect on English Consonan Learning and Its Countermeasures ,Shandong University, 2008

[3] C.D. Ma, "A Preliminary Comparative Study of Sichuan Dialect Phonology and English Phonology," Journal of Sichuan Teachers College (Social Science) issue 3,pp.11-16,1998.

[4] M.J. Liu, "Solutions to Negative Transfer of Chaoshan Dialects to English Pronunciation," Journal of Jianghan Petroleum University of Staff and Workers, issue 6, pp.91-93, 2014.

[5] Y.Z. Yin, "On the Block Sounds in Mulao Language,"Journal of Hech University, issue 5, pp.104-106,2004.

[6] Y.Z. Yin, "A Comparison of the Nasal and Block Sounds in Maonan Language with English Consonants," Journal of Hechi University, issue $1, \mathrm{pp} .43-45,2010$.

[7] J.E. Flege, The pronunciation of 'new' and 'similar' phones in a foreign language: eividence for the effect of equivalence classification. Journal of Phonetics, Vol. 15, pp.47-65,1987.

[8] Z. Liu, Chaozhou Dialect as a Negative Transfer in the Acquisition of English Phonetics_-A Contrastive Study of Phonemes of English Consonants and the Initial Consonants in Chaozhou Dialect. Journal of Zhanjiang Normal College 2009year05issue,74-78 2009. 